\title{
WDX Studies on Ceramic Diffusion Barrier Layers of Metal Supported SOECs
}

\author{
D. Wiedenmann ${ }^{1,2 *}$, U. F. Vogt ${ }^{2,3}$, C. Soltmann, O. Patz ${ }^{4}$, G. Schiller ${ }^{4}$, B. Grobéty ${ }^{1}$ \\ ' Department of Geoscience, University of Fribourg, Pérolles, 1700 Fribourg, Switzerland \\ 2 Laboratory Hydrogen \& Energy, Empa, Swiss Federal Laboratories for Material Testing and Research, Ueberlandstrasse 129, 8600 \\ Duebendorf, Switzerland \\ 3 Department of Crystallography, University of Freiburg, D-79104 Freiburg, Germany \\ 4 Institute of Technical Thermodynamics, DLR, German Aerospace Center, Pfaffenwaldring 38-40, 70569 Stuttgart, Germany
}

Received October 17, 2008; accepted March 26, 2009

\begin{abstract}
Solid oxide electrolyser cells (SOECs) have great potential for efficient and economical production of hydrogen fuel. Element diffusion between the Ni-cermet electrode and the metal substrate of metal supported cells (MSC) is a known problem in fuel cell and electrolysis technology. In order to hinder this unintentional mass transport, different ceramic diffusion barrier layers (DBLs) are included in recent cell design concepts. This paper is based on wavelength dispersive $\mathrm{X}$-ray fluorescence investigations of different SOEC and focuses on $\mathrm{Fe}, \mathrm{Cr}$ and $\mathrm{Ni}$ diffusion between the metal grains of the cathode and the metal substrate. Due to the low detection limits and therefore high analytical sensitivity, wavelength dispersive electron probe microanalysis (EPMA) provides a precise method to determine element distribution,
\end{abstract}

absolute element concentration and changes between the reference material and aged cells on a microstructural level by element mappings and concentration profiles. The results of this work show considerable concentration gradients in the metal grains caused by mass exchange during cell operation. Diffusion can be inhibited significantly by integrating different ceramic DBLs of doped $\mathrm{LaCrO}_{3}$-type or doped $\mathrm{LaMnO}_{3}$-type perovskite, either by vacuum plasma spraying (VPS) or physical vapour deposition technique (PVD).

Keywords: Degradation, Diffusion Barrier Layer, Electron Probe, Mass Transport, Microanalysis, Perovskite, Solid Oxide Electrolyser Cells, Solid Oxide Fuel Cells

\section{Introduction}

A porous cermet of $\mathrm{Y}_{2} \mathrm{O}_{3}$ stabilised $\mathrm{ZrO}_{2}$ (YSZ) and $\mathrm{Ni}$ is a commonly used material for the cathode in solid oxide electrolyser cells [1-3]. In metal supported cells (MSCs) from the German Aerospace Center (DLR) in Stuttgart, Germany [4], the Ni-cermet cathode material is directly deposited onto a porous metallic substrate of a Fe-Cr-Plansee alloy (oxide dispersive strengthened PM ODS-alloy) followed by the YSZelectrolyte and the $\mathrm{Sr}$ doped $\mathrm{LaMnO}_{3}$-anode (LSM) (Figure 1). As the Ni cermet is in direct contact with the substrate steel alloy, mutual element diffusion involving $\mathrm{Fe}, \mathrm{Cr}$ and $\mathrm{Ni}$ occurs between the substrate and the electrode causing unintentional chemical and structural changes. In this context, ceramic diffusion barrier layers (DBLs) of doped $\mathrm{LaCrO}_{3}-$ type and $\mathrm{LaMnO}_{3}$-type perovskite [5] developed by DLR [6, 7] have been integrated between the metal substrate and the cathode (Figure 1) in order to avoid these cell-degrading effects. In general, the DBLs have to ensure gas transport from the metal substrate towards the cathode and to cover the contact points between the particles of the electrode and the substrate to prevent element diffusion. This can be provided either by applying a thick layer $(\sim 50 \mu \mathrm{m})$ of certain porosity covering the entire surface of the porous metal substrate [Table 1: vacuum plasma spraying (VPS)-layer cell 2] or by closing the contact spots of the substrate particles which have physical contact with the cathode with a dense and thin $(5-10 \mu \mathrm{m})$ DBL [Table 1: physical vapour deposition technique (PVD)-layer cell 3] [7]. To quantify the diffusion process and to verify the efficiency of the barrier layers, post mortem investigations on cross-sections of three different electrolysis cells (Table 1) have been performed.

[*] Corresponding author, daniel.wiedenmann@empa.ch 


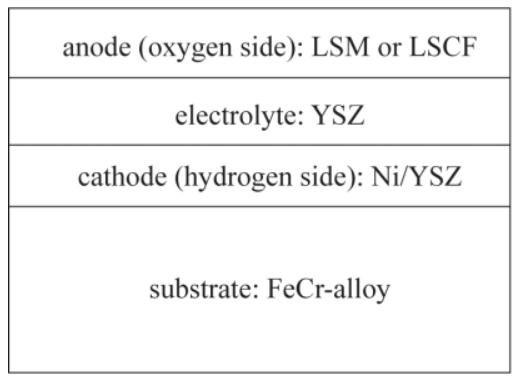

\begin{tabular}{|c|}
\hline anode (oxygen side): LSM or LSCF \\
\hline electrolyte: YSZ \\
\hline cathode (hydrogen side): Ni/YSZ \\
\hline barrier layer: doped perovskite \\
\hline substrate: FeCr-alloy \\
\hline
\end{tabular}

Fig. 1 Schematic of metal supported (MSC) SOECs. Left side, without DBL; right side, with a doped perovskite DBL between substrate and cathode.

\section{Experimental}

The investigated MSCs with circular shape $\left(12.5 \mathrm{~cm}^{2}\right)$ were fabricated by plasma spray technology at DLR Stuttgart [8,9]. The metal substrate is a $1 \mathrm{~mm}$ thick Fe-Cr ferritic steel alloy (Plansee, Austria) which is manufactured by a powder metallurgical process [10]. DBLs were deposited directly onto the substrate either by VPS (cell 2) or by the PVD technique [7] (cell 3), followed by plasma spray deposition of NiO/YSZ under atmospheric conditions (APS). The YSZ electrolyte was applied by VPS, the LSM anode was screen-printed or plasma sprayed onto the electrolyte layer. The cells first were activated in fuel cell mode in order to reduce the $\mathrm{NiO}$ to $\mathrm{Ni}$ followed by the electrolysis operation (Table 1).

For scanning electron microscopy (SEM) and electron probe microanalysis (EPMA) pieces of the analysed cells were cut in cross-section geometry and embedded with epoxy resin. A highly fluid resin with an adequate processing time (1 h) was used (Araldite BY158/Aradur 21). As the samples are composites of soft metal parts and hard ceramic material, a resistent resin was used for proper grinding. The resin was infiltrated into the sample first at about 20 mbar, then under over pressure ( 2 bars) to fill all free pore space of the porous cell parts. After grinding with $\mathrm{SiC}$ the samples were subsequently polished with diamond suspension (MetaDi monocrystalline diamond suspension from Buehler) down to $1 \mu \mathrm{m}$ grain size to provide a plane surface. The residual surface roughness was further reduced by chemical polishing with colloidal silica suspension (Masterprep Polishing Suspension 0.05 Micron from Buehler). Finally, the sample was covered by a thin C-film to make the surface electrically conductive.

Table 1 Operation conditions and type of DBL of investigated electrolyser cells. VPS: vacuum plasma spraying, PVD: physical vapour deposition technique.

\begin{tabular}{|c|c|c|}
\hline & Cell 1 & Cell 3 \\
\hline $\begin{array}{l}\text { Activation in fuel cell } \\
\text { mode }\end{array}$ & $\begin{array}{c}100 \mathrm{~h} \text { at } 800{ }^{\circ} \mathrm{C}, 200 \mathrm{~mA} / \mathrm{cm}^{2}, 0.5 \mathrm{l} / \mathrm{min} \mathrm{H}_{2} \\
0.5 \mathrm{l} / \mathrm{min} \mathrm{N}_{2}, 2.0 \mathrm{l} / \mathrm{min} \text { air }\end{array}$ & $\begin{array}{c}73 \mathrm{~h} \text { at } 800{ }^{\circ} \mathrm{C}, 200 \mathrm{~mA} / \mathrm{cm}^{2} \\
0.5 \mathrm{l} / \mathrm{min} \mathrm{H}_{2}, 0.5 \mathrm{l} / \mathrm{min} \mathrm{N}_{2} \\
2.0 \mathrm{l} / \mathrm{min} \text { air }\end{array}$ \\
\hline Electrolysis cell mode & $130 \mathrm{~h}$ at $800{ }^{\circ} \mathrm{C},-200 \mathrm{~mA} / \mathrm{cm}^{2}$ & $2,030 \mathrm{~h}$ at $800{ }^{\circ} \mathrm{C},-300 \mathrm{~mA} / \mathrm{cm}^{2}$ \\
\hline $\begin{array}{l}\text { Diffusion barrier } \\
\text { layer (DBL) }\end{array}$ & $\begin{array}{c}\text { Doped } \mathrm{LaCrO}_{3} \text {-type } \\
\text { perovskite }\end{array}$ & Doped $\mathrm{LaMnO}_{3}$-type perovskite \\
\hline $\begin{array}{l}\text { DBL deposition- } \\
\text { technique }\end{array}$ & VPS & PVD \\
\hline
\end{tabular}

The as-prepared cross-sections were investigated by SEM- and EPMA-technique (Philips XL30 ESEM-FEG and Jeol Superprobe 8800). EPMA is an experimental wavelength dispersive X-ray technique (WDX) to determine chemical compositions on a microstructural level at high accuracy. The measurements are carried out by measuring the energy and intensity distribution of the $\mathrm{X}$-ray signals generated by a focused electron beam. In contrast to energy dispersive spectrometry (EDS), EPMA takes the advantage of the wave nature of photons as specific X-rays are diffracted and isolated according to their wavelength by means of Bragg reflection on an analysing crystal. WDS is performed with an electron probe microanalyser, which is an adapted scanning electron microscope equipped with several spectrometers for simultaneous measurements of different elements. Since in an EPMA-spectrometer certain characteristic X-ray photons of relevant chemical elements can be selected and isolated from other emitted X-ray photons, the peak-background ratio and the spectral resolution of WDS are much higher in relation to EDS. EDS detectors are collecting all X-ray photons emitted from the sample so that measurements are fast but the accuracy is low compared to WDS analysis. Therefore, the WDX technique has only little peak overlap of characteristic $\mathrm{X}$-rays of similar energy, lower detection limits and therefore a higher accuracy (Figure 2). SEM imaging and two-dimensional X-ray element mappings (EPMA) were done to verify the regularity of the respective barrier layer. Quantitative measurements were carried out by EPMA on metal grains to quantify the $\mathrm{Fe}, \mathrm{Cr}$ and $\mathrm{Ni}$ mass transport due to diffusionprocesses during cell operation for cells with and without a DBL. After operation, concentration gradients in the metal grains of the cathode and the substrate of aged cells were determined. Quantitative EPMA measurements were carried out at $25 \mathrm{kV}$ and $3 \times 10^{-8} \mathrm{~A}$, element mappings at $15 \mathrm{kV}$ and $3 \times 10^{-8} \mathrm{~A}$.

\section{Results and Discussion}

Owing to kinetic reasons, the diffusion of $\mathrm{Fe}, \mathrm{Cr}$ and $\mathrm{Ni}$ between the cell electrode and the substrate takes place over the particular metal-phase distribution via solid-state reactions. Diffusion of Fe and $\mathrm{Cr}$ occurs over the Niparticles, diffusion of $\mathrm{Ni}$ over the grains of the FeCr-substrate respectively.

In cell 1 , a cell without a DBL, the $\mathrm{Ni}$ grains of the cathode are in direct contact with the substrate alloy at the interface [Figures 3(a) and 4]. In this case, our EPMA investigations 


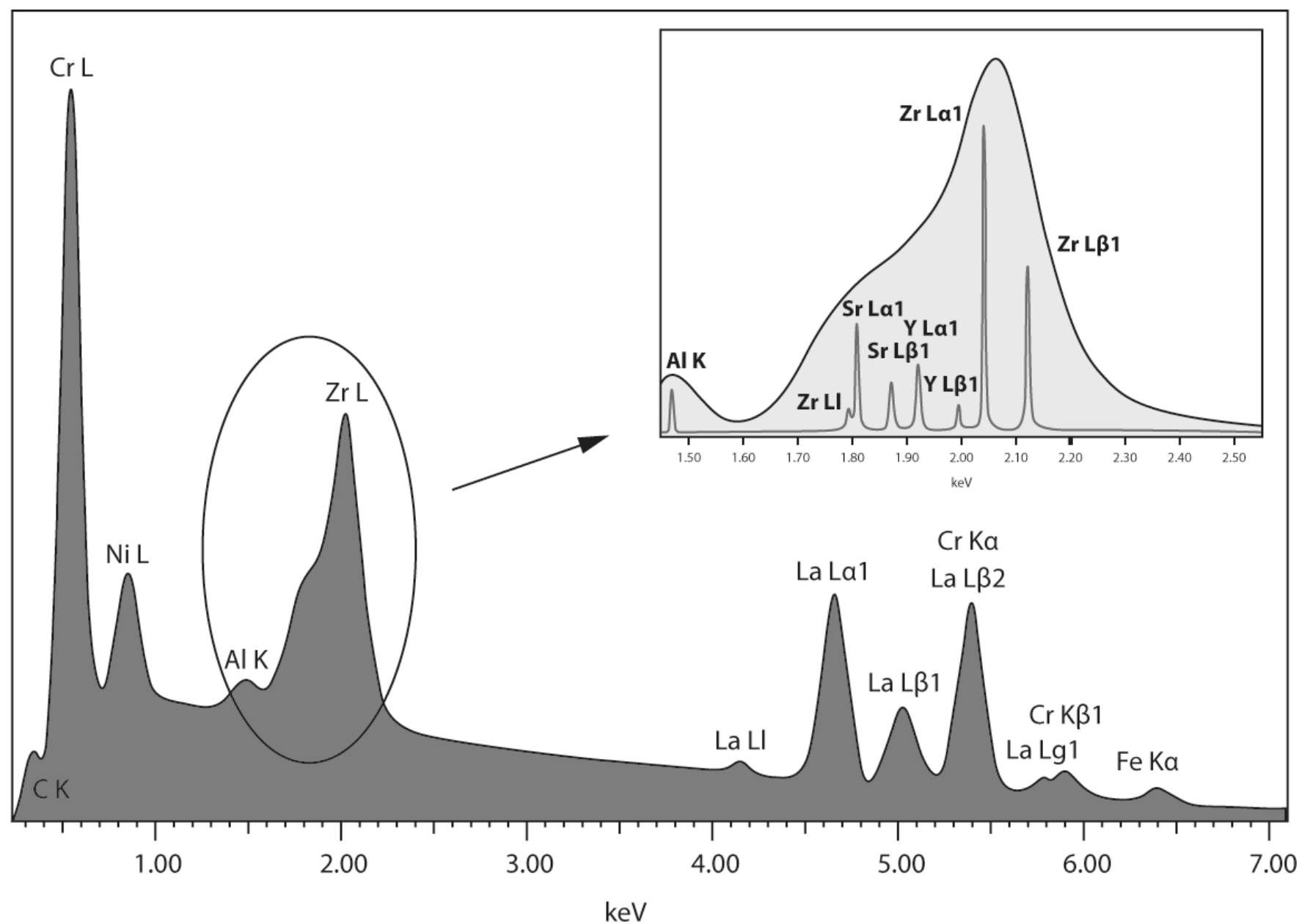

Fig. 2 X-ray spectra at $15 \mathrm{kV}$ of cell 3 showing the improved spectral resolution of EPMA compared to EDX. Outer-frame, EDX-spectrum; inner-frame, WDX-spectrum from 1.50 to $2.50 \mathrm{keV}$ compared to EDX- peak of $\mathrm{Zr} \mathrm{La}$.

revealed significant mass exchange between the metal substrate and the cathode (Figure 4) after $230 \mathrm{~h}$ under electrolysis conditions. A considerable amount of iron and chromium was detected in $\mathrm{Ni}$ grains of the electrode. Conversely, $\mathrm{Ni}$ was found in the metal substrate alloy material. Quantitative analysis showed that around $17 \%$ of the $\mathrm{Ni}$ atoms in grains at the interface were substituted by $\mathrm{Fe}$ and $\mathrm{Cr}$, converting the $\mathrm{Ni}$ phase into a Ni-based alloy. Corresponding to the chemical changes, the oxidation behaviour altered and the electrochemical activity decreased, which resulted in an unintentional decrease in the cell performance. Measurements on the substrate grains showed a distinct decrease in the $\mathrm{Cr}$-content of up to $50 \mathrm{wt}$-\% due to Cr-loss compared with the virgin steel substrate (initial composition: $\mathrm{Fe}, 26 \mathrm{Cr}$ ). The highest $\mathrm{Ni}$ concentration measured in the metal substrate is approximately $4 \mathrm{wt.}$ - $\%$, whereas the original ferritic steel alloy is altered at least partially into an austenitic structure [3]. This increases the coefficient of thermal expansion which can cause cracks in the substrate lowering the long-term stability and cell performance.

A possibility to suppress the metal element diffusion in order to avoid the associated structural and chemical changes is the integration of a DBL between the cathode and the substrate. As element diffusion takes place over the contact points between $\mathrm{Ni}$ and the alloy grains, closing these diffusion tracks by integrating a barrier layer inhibits the mass transport. Nevertheless, this barrier layer has to be either porous enough to ensure the gas distribution or to be limited spatially to the contact points without influencing the percolative pore-structure of the substrate/electrode interface.

Diffusion was inhibited succesfully in cell 2 by an approximately $50 \mu \mathrm{m}$ thick VPS made $\mathrm{LaCrO}_{3}$-type perovskite barrier layer [Figure 3(b) and 5]. The quantitative measurements showed that less than $0.4 \%$ of the $\mathrm{Ni}$ atoms were replaced by Fe and $\mathrm{Cr}$ (Figure 5). Equally, the $\mathrm{Cr}$ content of the steel substrate decreased only by $20 \mathrm{wt} .-\%$. Both, Ni in the substrate and $\mathrm{Fe}$ in the electrode replace less than $0.1 \%$ of the primary metal atoms after $230 \mathrm{~h}$ of cell operation. Only approximately 0.3 wt.- $\%$ Cr was detected in the $\mathrm{Ni}$ grains of the cathode of cell 2 . Compared to cell 1 , the degradation process was significantly suppressed as almost no Fe and Ni diffusion occured. The source of $\mathrm{Cr}$ is either the $\mathrm{DBL}$ itself as it is a $\mathrm{LaCrO}_{3}$-type perovskite or the cell substrate. 
cell without DBL

\begin{tabular}{|r|}
\hline anode (oxygen side): LSM or LSCF \\
\hline electrolyte: YSZ \\
\hline cathode (hydrogen side): Ni/YSZ \\
\hline section a) \\
cell 1 \\
substrate: FeCr-alloy \\
\hline
\end{tabular}

cell with DBL

\begin{tabular}{|c|c|}
\hline \multicolumn{2}{|c|}{ anode (oxygen side): LSM or LSCF } \\
\hline \multicolumn{2}{|c|}{ electrolyte: YSZ } \\
\hline \multicolumn{2}{|c|}{ cathode (hydrogen side): Ni/YSZ } \\
\hline barrier & layer \\
\hline \multicolumn{2}{|c|}{$\begin{array}{l}\text { section } b \text { ) and c) } \\
\text { cell } 2 \text { and } 3\end{array}$} \\
\hline \multicolumn{2}{|c|}{ substrate: FeCr-alloy } \\
\hline
\end{tabular}

Fig. 3 Schematics of SOECs (left side) and WDX element mappings (right side) showing the interface cathode/substrate of the investigated SOECs. Cell 1, without a DBL, cathode and substrate are in direct contact; Cell 2, doped VPS LaCrO -perovskite DBL between electrolyte and cathode; Cell 3, doped PVD LaMnO 3 -perovskite DBL. Scale in $\mu \mathrm{m}, 15 \mathrm{kV} 3 \times 18^{-8} \mathrm{~A}$.

The PVD processed DBL of cell 3 has a reduced thickness of less than $5 \mu \mathrm{m}$ [Figure 3(c) and 6], which is around $1 / 10^{\text {th }}$ of the VPS processed layer-thickness of cell 2. The Cr content of the steel substrate decreased by approximately $40 \mathrm{wt} .-\%$ (Figure 6). Maximal $1.5 \%$ of the $\mathrm{Ni}$ atoms of the electrode close to the interface were substituted by $\mathrm{Fe}$ and $\mathrm{Cr}$ after $2,030 \mathrm{~h}$ of electrolysis operation. The highest $\mathrm{Ni}$ concentration in the substrate is around $0.5 \mathrm{wt} . \mathrm{\%} \%$. According to the presented quantitative analysis, the degradation process in the long-time study of cell 3 was reduced by factor 10 in rela- tion to cell 1, while the operating time was about 9 times longer.

\section{Acknowledgements}

This work was carried out with financial support from the European Commission under the 6th Framework Programme, 6.1.ii, Sustainable Energy Systems, in the Integrated Project Hi2H2 (contract no. 503765). We acknowledge the European Commission for supporting the Hi2H2 project. 

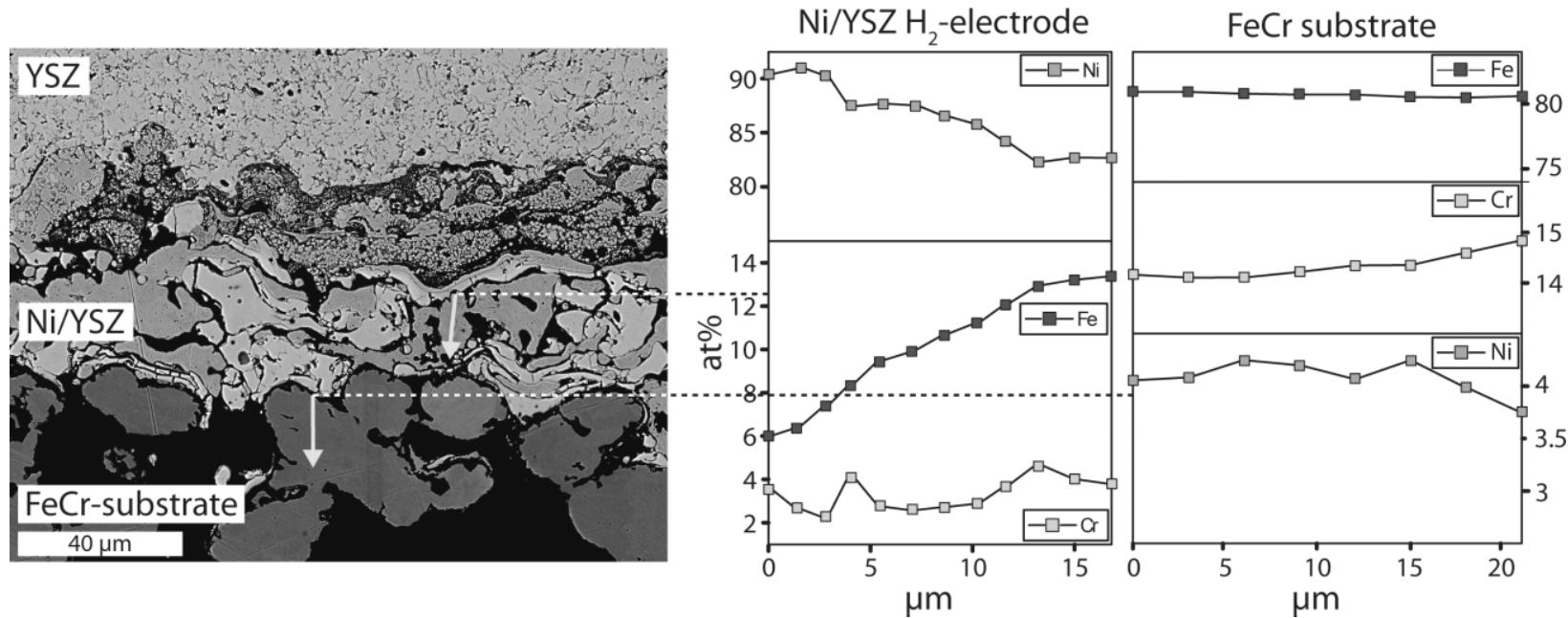

Fig. 4 Backscattered electron (BSE) image (left) and element diffusion diagram (right) of the cathode/substrate interface of cell 1 (without a DBL) after $230 \mathrm{~h}$ of operation. The diagram corresponds to the arrows in the BSE-image showing significant mass exchange due to element diffusion.
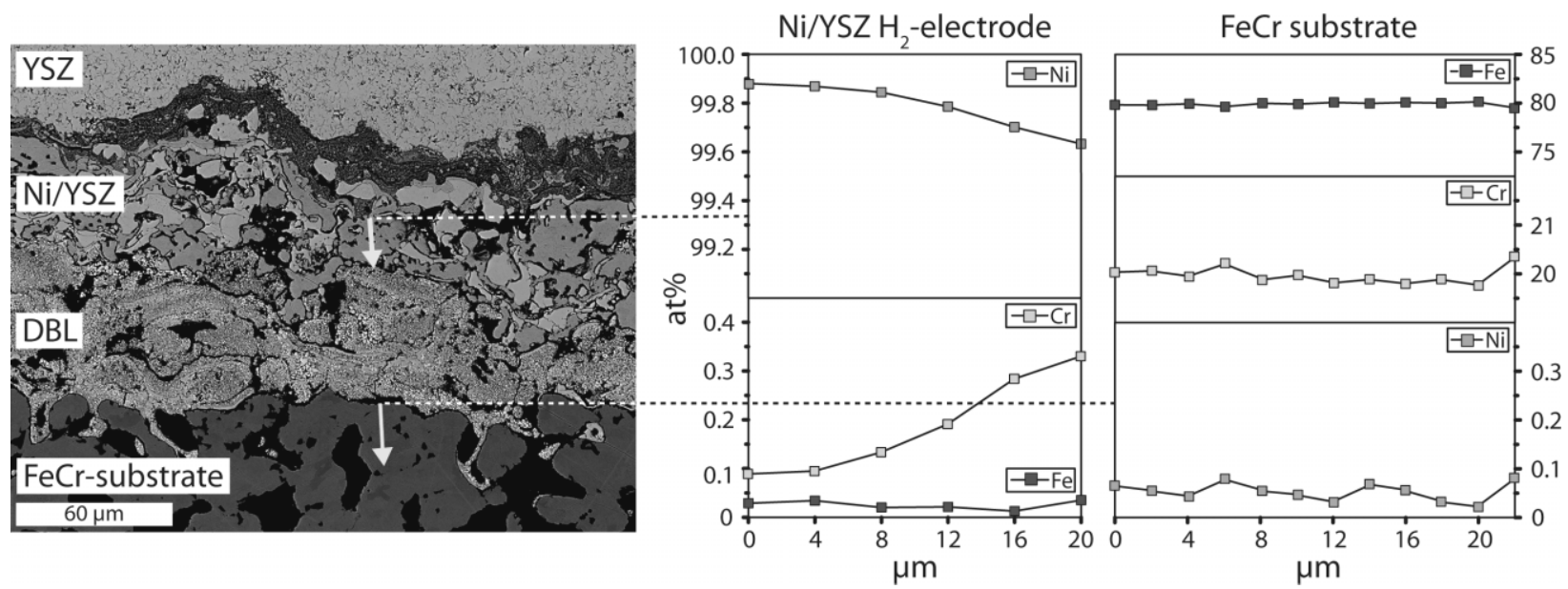

Fig. 5 BSE image (left) and element diffusion diagram (right) of the cathode/DBL/substrate interface of cell 2 (doped LaCrO 3 -type VPS DBL) after $230 \mathrm{~h}$ of operation. The diagram corresponds to the arrows in the BSE-image. Element diffusion was succesfully inhibited by the integrated DBL.
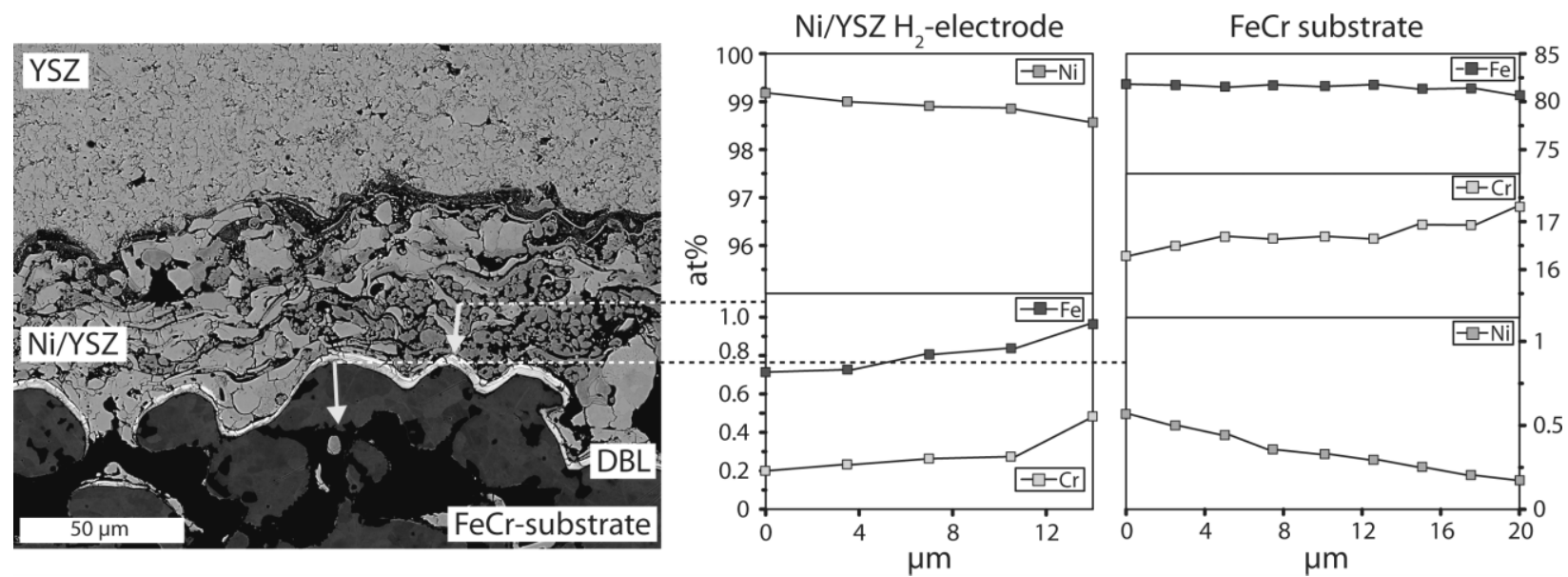

Fig. 6 BSE image (left) and element diffusion diagram (right) of the cathode/DBL/substrate interface of cell 3 (doped LaMnO3-type PVD DBL) after $2,030 \mathrm{~h}$ of electrolysis operation. The diffusion diagram corresponds to the arrows in the BSE-image. Element diffusion was succesfully inhibited by the DBL. Note that the PVD-layer is only 5-10 $\mu \mathrm{m}$ thick and is integrated between the Ni/YSZ electrode and the FeCr-substrate. 


\section{References}

[1] P. Holtappels, U. Stimming, Solid oxide fuel cells (SOFC) in Handbook of Fuel Cells - Fundamentals, Technology and Applications 2005, Vol. 1, p. 335.

[2] A. Hauch, S. H. Jensen, M. Mogensen, S. Rasmousse, Performance and Durability of Solid Oxide Electrolysis Cells, J. Electrochem. Soc. 2006, 153, A1741.

[3] A. Hauch, S. D. Ebbesen, S. H. Jensen, M. Mogensen, J. Electrochem. Soc. 2008, 155, 1184.

[4] G. Schiller, A. Ansar, M. Lang, O. Patz, J. Appl. Electrochem. 2009, 39, 2, 293.

[5] U. F. Vogt, J. Sfeir, J. Richter, C. Soltmann, P. Holtappels, Pure Appl. Chem. 2008, 80, 2543.

[6] T. Franco, K. Schibinger, Z. Ilhan, G. Schiller, A. Venskutonis, J. Appl. Electrochem. 2002, 32, 871.
[7] G. Kunschert, K. H. Kailer, S. Schlichtherle, G. N. Strauss, Ceramic PVD Coatings as Dense/Thin Barrier Layers on Interconnect Components for SOFC Applications in 10th Int. Symp. on Solid Oxide Fuel Cells (SOFC X), Nara, Japan, 2007, p. 2407.

[8] G. Schiller, R. Henne, M. Lang, M. Müller, Development of solid oxide fuel cells by applying DC and RF plasma deposition technologies in Fuel Cells - From Fundamentals to Systems, 2004, Vol. 4, p. 56.

[9] A. A. Syed, Z. Ilhan, J. Arnold, G. Schiller, H. Weckmann, J. Therm. Spray Technol. 2006, 15, 617.

[10] A. Venskutonis, G. Kunschert, Powder Metallurgical Processing of Interconnect Materials and Components for Stationary and Mobile SOFC Applications in Proc. 7th European SOFC Forum, Lucerne, Switzerland, 2006, p. BO85. 